\title{
The Rosetta Stone and the Nemrud Nomos: the discovery of significant textual and astronomical similarities
}

Maurice Crijns (iD) ${ }^{1 \times}$

Commagene was an independent and wealthy kingdom in the east of present Turkey from ca. 160 to 20 BCE. A text referred to as Nomos (Dörner) describes the astro-religion of Commagene (Crijns). The text on the Egyptian Rosetta Stone describes the Ptolemaic astroreligion (Rosetta Stone Online Project). It is shown here that the Rosetta text is a precursor of the Nomos, based on textual and astronomical evidence. The coronation dates as mentioned in both texts display a similar configuration in the sky as substantiated by the configuration on the Lion Horoscope at the top of Mt. Nemrud. Not only the date can be calculated, but also the precise time. The time is determined by an annual phenomenon of the marker star Sirius and Regulus, respectively. The latter has been overseen by scholars and underlines the importance of having at least a basic understanding of archaeoastronomy. These unnoticed similarities indicate that the astro-religions of the Middle East are not stand alone cults. The significant similarities point at a shared heritage i.e., a star cult dating maybe as far back as the era of the Fertile Crescent at the dawn of mankind.

\footnotetext{
${ }^{1}$ International Nemrud Foundation, Geldrop, The Netherlands. ${ }^{凶}$ email: m.crijns@nemrud.nl
} 


\section{Introduction}

he Nomos of Commagene is proclaimed by king Antiochus I (Dörner and Young, 1996; Crijns, 2014). The text is inscribed at the back of five colossal statues on top of Mt. Nemrud, the paramount sanctuary (Fig. 1).

The Rosetta text is proclaimed by the Egyptian priests, who glorify the benevolent Ptolemaic king and his divine cult. The Ptolemies issued a series of decrees to cement their rule over the course of their reign (Manning, 2012). ${ }^{1}$ The Rosetta Stone of Ptolemy V is the most famous one, because it enabled the deciphering of hieroglyphs (Wallis Budge, 1913). ${ }^{2}$ The decree was issued in $196 \mathrm{BCE}$ on behalf of king Ptolemy V to commemorate his coronation nine years before, in 205 BCE. In that year, his father Ptolemy IV assigned his five year old son as co-ruler. The coronation of the boy was an excellent opportunity to reinforce his rule. To create more acceptance from the native Egyptians, Ptolemy IV shifted the location of the ceremony from the Macedonian capital Alexandria to Memphis, the ancient capital of Egypt.

\section{The marker stars Regulus and Sirius}

Contrary to modern man, the ancients had no calendar to plan activities. The monthly moon phases were ideal to plan short term events. For that reason, most of the ancient calendars started as a lunar calendar (Parker, 1950). To plan longer term events, the ancients used the stars. They observed that stars contrary to planets, have a fixed course and position in the sky (Aratus, 2006). ${ }^{3}$ The stars are visible and invisible in a fixed, annual pattern. An agricultural marker star is a star of which the visibility cycle coincides with the agricultural seasons in a certain region (Hesiod, 2004). The ancients used them to create a star calendar. Some of these calendars are in use until today, as in Yemen (Varisco, 1993).

Four thousand years ago, Egypt developed a star calendar based on the marker star Sirius. In ancient times, the astronomical knowledge of the Egyptians was highly regarded (Diodorus, 2018). This knowledge was out of necessity: Egypt has little rainfall and agriculture depended completely on the annual flooding of the Nile. Consequently, all crops had to fit into the

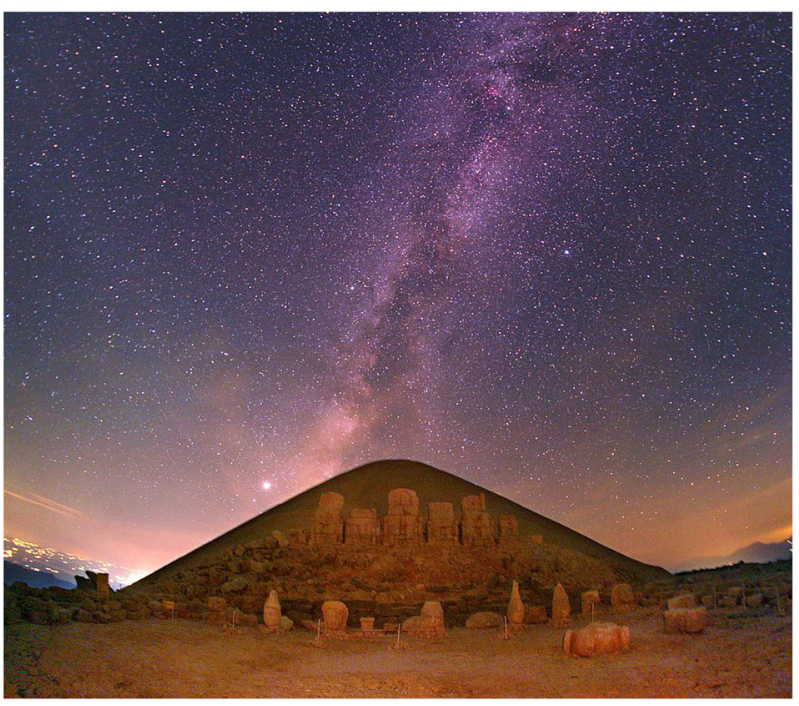

Fig. 1 The main sanctuary of Commagene on top of Mt. Nemrud. View from the East terrace at dawn, the Milky Way above the tumulus and Jupiter to the left of the statues. Photo by Tunç Tezel. This figure is not covered by the Creative Commons Attribution 4.0 International License. Reproduced with permission of Tunç Tezel; copyright (c) 2008 Tezel, all rights reserved. tight scheme of inundation and irrigation. The preparations required precise timing as imprecise timing could mean famine. Two phenomena of Sirius provided for that timing. The reappearance of the annual flood coincided with the annual reappearance of Sirius. After almost seventy days absence, Sirius could be seen again. Notably, the mummification of the deceased took also seventy days (Gautschy, 2011). At dawn on the 18th of July, Sirius appeared in the east, heralding the flood. This phenomenon is known as the apparent morning rising, AMR (Robinson, 2009).

Next, the surfacing of the flooded land coincided with the disappearance of Sirius. At dawn on the 28th of November, Sirius could be seen for the last time setting in the west, known as the apparent morning setting, AMS. Then, the planting season started.

Regulus, the marker star of Commagene provided for two annual phenomena which coincided with agricultural events. The main crop was barley, planted in January-February. The 25th of January was the day of the last visible setting of Regulus or AMS. The time to harvest was in July-August. The 14th of July was the last day that Regulus could be seen, known as the apparent evening setting, AES.

Subsequently, the ancients connected the star calendar to religious events culminating in an astro-religion as described in the Ptolemaic Rosetta text and the Commagenian Nomos.

\section{Rosetta and Nomos}

Both texts follow a similar pattern: First, a general introduction of the king, followed by a list of his accomplishments and ending with a detailed description of his cult. Both texts were publicly displayed on steles all over the land. Rosetta: '...each of the first and second and third rank temples'. Steles with the Nomos were found in sanctuaries throughout Commagene (Fig. 2). Both kings associated themselves with a star and not a planet. Antiochus with Regulus: 'Antiochos choose the royal star Regulus, ... as the image of himself' (Dörner, 1987). And the Ptolemies with the Sun. Rosetta: '...king like the Sun'. The connection with a star suggested that the king was a beacon of reliability (Figs 3,4$).{ }^{4}$ Following dates are stated.

Rosetta:

- Birthday of Ptolemy V: '...the 30th of Mesore, on which the birthday of the king is celebrated,...' (regnal year 12 of Ptolemy IV) or 9th of October 210 BCE.

- Coronation of Ptolemy V: '...the 17th of Phaophi on which he inherited the kingship from his father.' (regnal year 1 of Ptolemy V) or 28th November 205 BCE.

- Erection of the stele: '...in the month Xandikos, day 4 and of the Egyptian Mekheir, day 18' (regnal year 9 of Ptolemy V) or 27th of March 196 BCE.

Nomos:

- Birthday of Antiochus I: 'The birthday of my natural body, the sixteenth of Audnaios...'. Scholars suggest that this must be a day in December/January (Dörner and Young, 1996).

- Coronation of Antiochus I: '.... and the tenth of Loos, the day of my accession to the throne,...' Scholars suggest that this must be a day in July (Dörner and Young, 1996).

Though the Nomos states no date of erection, both mention the same festivals to be celebrated i.e., the coronation and the birthday of the king. Both state that these days had to be celebrated annually. Rosetta: 'And since the thirtieth of Mesore, on which the birthday of the King is celebrated, likewise the 


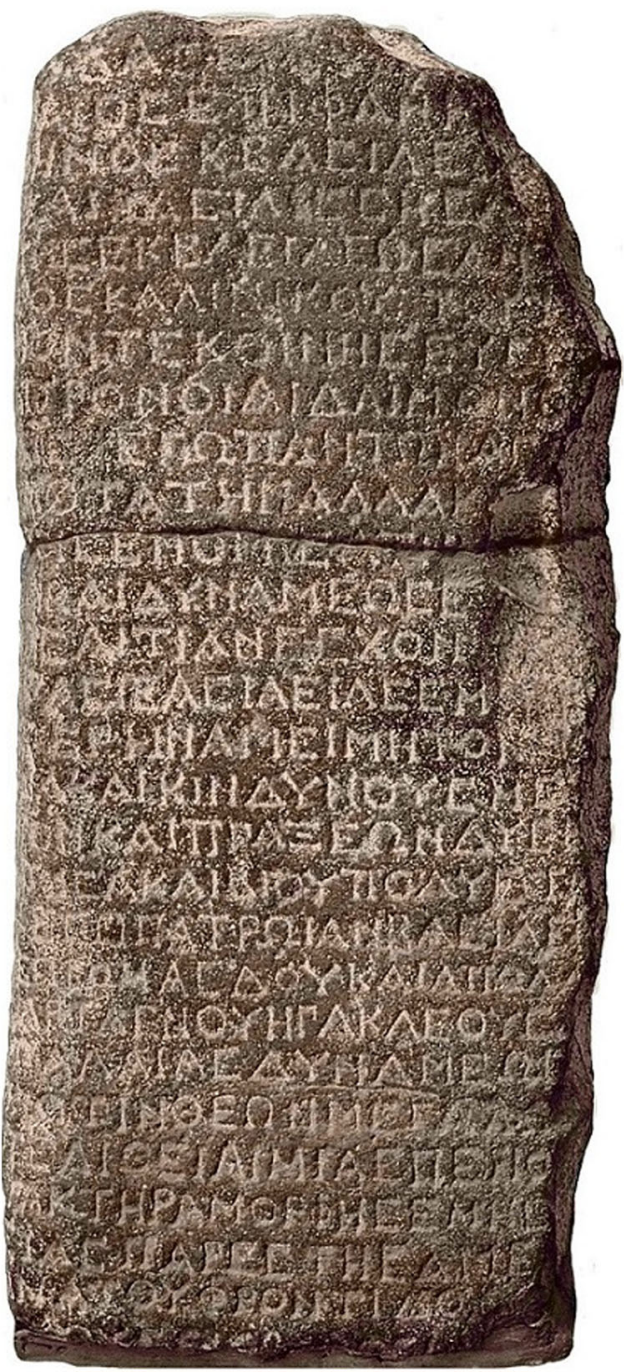

Fig. 2 Nomos. Nomos stele from Samosata, capital of Commagene. Brijder, H.A.G. Nemrud Dağı (2014), fig. 84c. This figure is not covered by the Creative Commons Attribution 4.0 International License. Reproduced with permission of Herman Brijder; copyright (c) 2014 Brijder, all rights reserved.

seventeenth of Phaophi on which he inherited the kingship from his father.' Nomos: 'The birthday of my natural body, the sixteenth of Audnaios, and the tenth of Loos, the day of my accession to the throne, I have consecrated to the manifestation of the great deities,...' Both texts state that these days must be celebrated monthly, Rosetta: '...to celebrate these days as festival and feast in the temples throughout Egypt every month'. Nomos: 'my birth on the sixteenth and my accession on the tenth shall be observed every month'.

The similarities of both texts are remarkable. It becomes even more fascinating when we look at the celestial configurations of these dates from an astronomical point of view.

Scholars suggest that the Egyptian and Commagenian birthdays are ceremonial and not actual dates: 'I am inclined, to consider ... the 16. Audnaios as mentioned in the inscriptions as the official i.e., the sacral birthday of the King' (Dörner and Goell, 1963). Koenen argues that the birthdates of Ptolemy II and Ptolemy III are official festivals. He notes that 30th of Mesore corresponds to a major Egyptian festival (Koenen, 1977). In any case, a birthday cannot be chosen. A coronation day or the day of the placement of a stele can be chosen freely. Naturally, such a

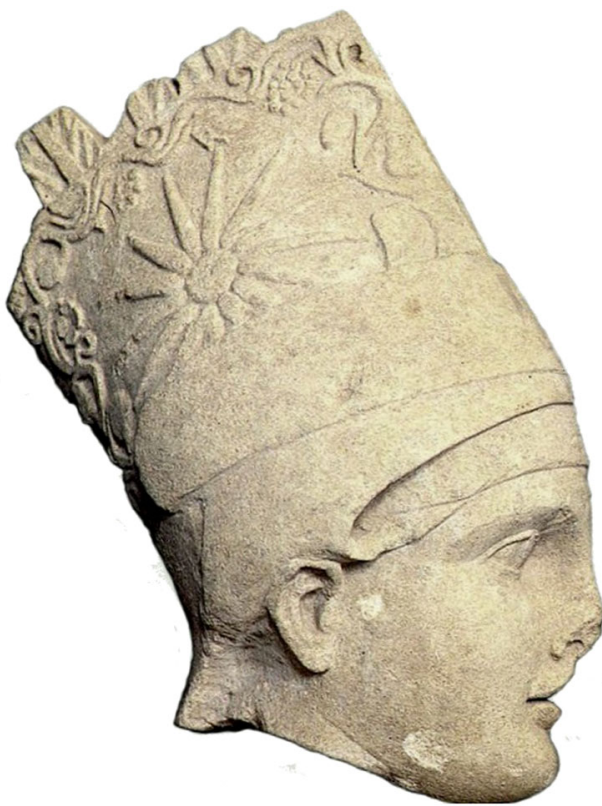

Fig. 3 King Antiochus I. Head of king Antiochus with Regulus on tiara. Brijder, H.A.G. Nemrud Dağı (2014), fig. 184a. This figure is not covered by the Creative Commons Attribution 4.0 International License. Reproduced with permission of Herman Brijder; copyright (c) 2014 Brijder, all rights reserved.

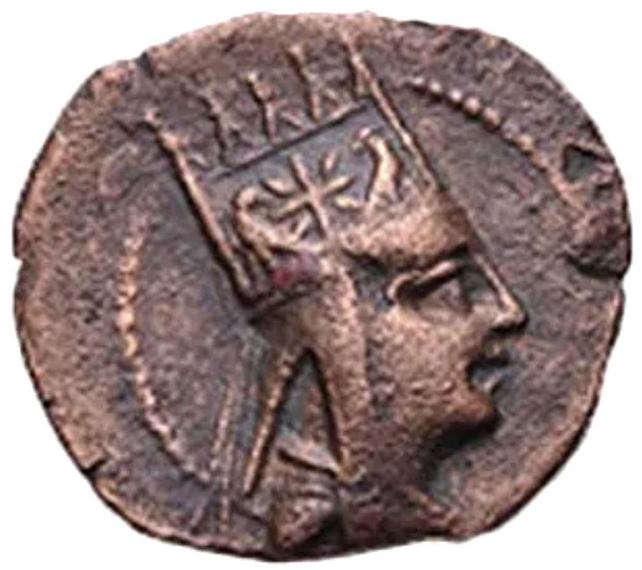

Fig. 4 Coin of King Antiochus I. King Antiochus with Regulus on tiara flanked by two eagles. Alram, M. Nomina Propria Iranica in Nummis (1986), p 240. This figure is not covered by the Creative Commons Attribution 4.0 International License. Reproduced with permission of Michael Alram; copyright (c) 1986 Alram, all rights reserved.

day should display to the people an explicit visible and beneficial configuration of the celestial bodies.

\section{Method}

The astronomical data as mentioned, have been calculated with the astronomical programs:

1. SkyMap Pro version 12, C.A. Marriott of SkyMap Software, United Kingdom.

2. Stellarium version 0.19.3. Stellarium is a free open source planetarium. It shows a realistic sky in $3 \mathrm{D}$, what you see with the naked eye, binoculars or a telescope. 
The data of ancient Egypt have been converted with the online Data Converter for Ancient Egypt version 0.11 of Grieshaber, Seminar für Alte Geschichte und Epigraphik, Heidelberg, http:// aegyptologie.online-resourcen.de/home.

The selected date for the coronation is the 28th of November 205 BCE. That day coincides with the annual, last visible setting of Sirius. The phenomenon was visible in the early morning. At dawn, Sirius and all planets were visible, even Mercury. Most of the time, Mercury cannot be seen, because of its close proximity to the Sun. The Sun was an important symbol to the Egyptians and, as well as the Macedonians (Walbank, 2006). And so, the rising Sun emphasized the shared adoration of the Egyptian people and Macedonian ruler class. The last visible setting of Sirius fostered the benevolence of the native Egyptians. The setting of Sirius was a brief moment due to the imminent rising Sun. That exact moment was the time of the coronation of the king in Memphis around 6:10 local time. The calculation is based on an

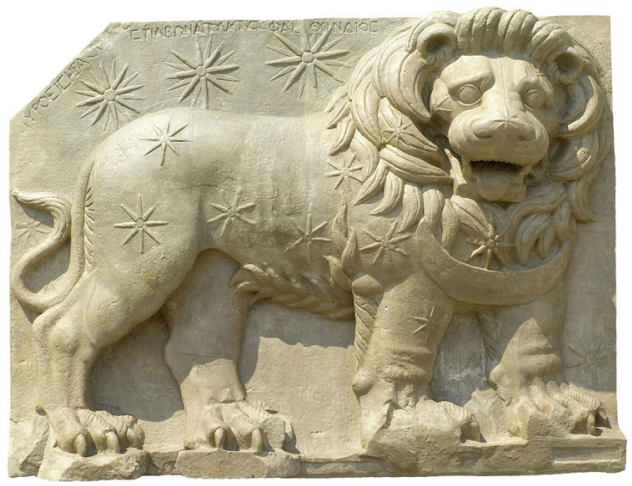

Fig. 5 The Lion horoscope. A complete copy of the original stele as found, donated by the International Nemrud Foundation to the Pierson Museum in Amsterdam, The Netherlands. Photo by Maurice Crijns. This figure is not covered by the Creative Commons Attribution 4.0 International License. Reproduced with permission of Maurice Crijns; copyright (c) 2004 Crijns, all rights reserved.
AMS (Robinson, 2009) at nautical twilight with altitude Sun $-7^{\circ}$ and altitude Sirius $+2^{\circ}$ (de Jong, 2006).

In Commagene, Mt. Nemrud was an excellent location to observe the stars and keep track of the phenomena of Regulus. The Lion Horoscope is a stele of an ensemble of five at the West terrace of the mountain. The relief depicts a lion dotted with the stars of the constellation Leo. Regulus is depicted at the heart of the lion above the crescent moon. Above the back of the lion, the planets Mars, Mercury and Jupiter are depicted with their names inscribed above (Fig. 5). The relief displays the celestial configuration as seen from the West terrace on the 14th of July 109 BCE. This calculated day coincides with the annual, last visible setting of Regulus referred to as AES (Robinson, 2009). At dusk, Regulus, Saturn, Jupiter, Mars, and even Mercury were visible. Due to the imminent setting of Regulus in the west, the phenomenon was visible but for a brief moment (see Fig. 6). That was the time of the coronation of the king on the West terrace on Mt. Nemrud (Crijns, 2002). The time is calculated as 20:02 local time. The calculation is based on an AES at nautical twilight with altitude Sun $-8^{\circ}$ and altitude Regulus $+0.5^{\circ}$.

\section{Results}

Both texts follow a similar pattern and were displayed on steles spread across the kingdom. Both kings identified themselves with a star. Both texts state the same festivals i.e., the royal birthday and the coronation day. Both were celebrated annually, as well as monthly. In both celestial configurations, the Sun is located at a cardinal point. The planets are visible, even Mercury. The time of both coronations is determined by the setting of their marker stars i.e., Sirius of Egypt and Regulus of Commagene. The decrees, as well as the celestial configurations of the coronation dates are similar. Such configurations are rare: 'That this specific planetary configuration [read: Lion Horoscope] can be found in the era of Commagene and not in any other era over a period of 10,000 years is unique and statistically significant' (Crijns, 2014).

An explanation of the similarities may be that the Ptolemaic Rosetta text was a blueprint for the Nomos decree of Antiochus. Another explanation may be that the texts were designed independently i.e., the Rosetta and the Nomos cult developed

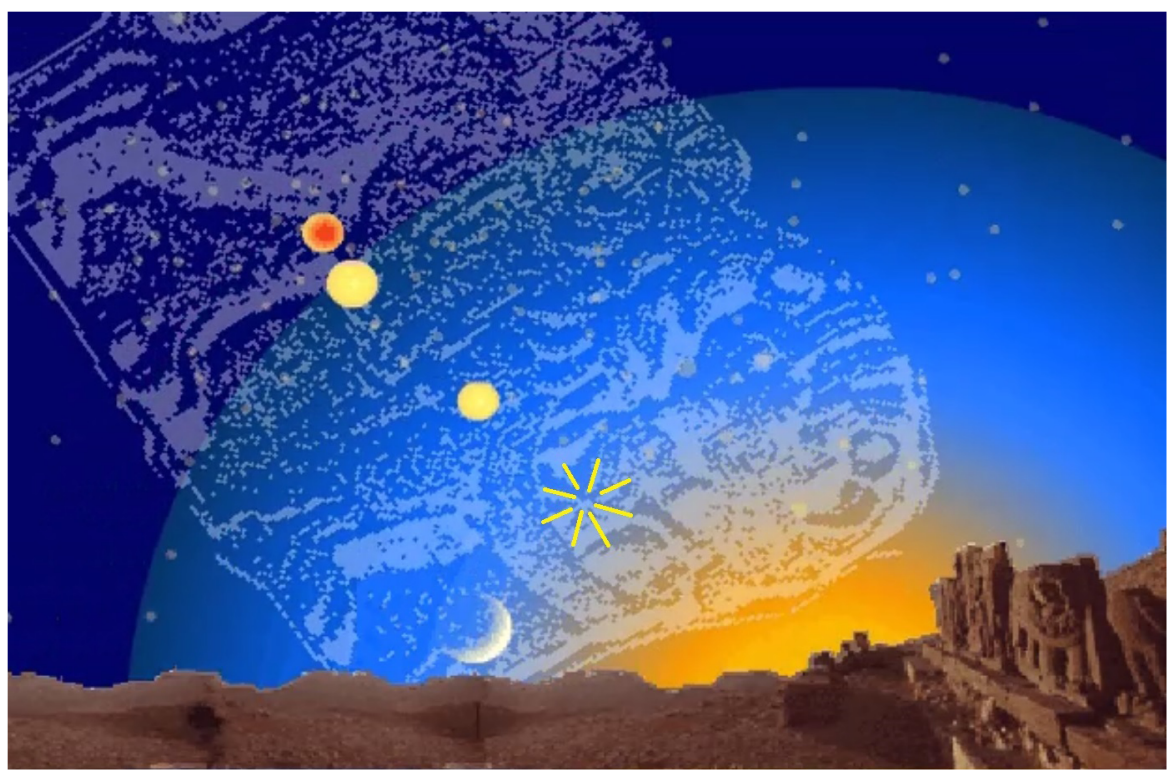

Fig. 6 Artist impression of the actual configuration. The configuration as seen at dusk from the West terrace of Mt. Nemrud on the 14 th of July 109 BCE at 20:02 local time. Note the ensemble of five steles at the right pointing to the celestial configuration in the west. Image by Maurice Crijns. This figure is not covered by the Creative Commons Attribution 4.0 International License. Reproduced with permission of Maurice Crijns; copyright (C) 2004 Crijns, all rights reserved. 
independently. In that case, the significant similarities point at a shared heritage i.e., a star cult dating from earlier times, maybe as far back as the era of the Fertile Crescent at the dawn of mankind.

\section{Discussion}

The phenomena in the heavens are strongly anchored in the cults of all ancient civilizations.

A basic knowledge of astronomy is required to understand the mindset of the ancients. Sir Norman Lockyer wished that 'every archaeologist would learn just a little astronomy' (Michell, 1977).

Archaeoastronomy is a great step forward, but does not provide for a basic knowledge among the common archeologist. In depth archaeoastronomical research is required to understand the interrelated connections of the cultures in the Middle East i.e., the Fertile Crescent.

\section{Data availability}

The datasets analyzed during this study are available in the Research Gate repository: https://www.researchgate.net/publication/3412333 15_DATA_REPOSITORY_Rosetta_Stone_Crownings_horoscope_Ptolemy_V_of_Egypt_and_of_Mithridates_I_of_Commagene_ie_the_Lion_HoroscopeDate_proleptic_Julian_calendar. These datasets were derived from the following public domain resources: 1 . The Rosetta Stone Online project repository, http://hdl.handle.net/ 21.11101/0000-0001-B537-5, accessed: 1 Sept 2019.2. Data Converter for Ancient Egypt repository, http://aegyptologie.onlineresourcen.de/ptolemies, accessed: 3 Jan 2020.

Received: 15 February 2020; Accepted: 12 May 2020;

Published online: 17 June 2020

\section{Notes}

1 Manning discusses the Decree of Alexandria in 243 BCE, the Decree of Canopus in 238 BCE, the Memphis decree of Ptolemy IV around 218 BCE and several others.

2 Two other artefacts helped to complete the deciphering of the hieroglyphs as discussed by Budge: The Nubayrah stele records the same decree as on Rosetta. The Philae obelisk dating 118 or $117 \mathrm{BCE}$, has a different text in hieroglyphic script and Koine Greek.

3 No wonder, that the common people connected the unpredictable deities to the unpredictable planets. The mood of deities could shift from benevolent to malevolent. Prayers and offerings were necessary to stay on good terms with them.

4 A tradition that stretched as far as ancient China, where the Pole Star was a metaphor for the emperor (Confucius, Analects 2.1).

\section{References}

Aratus (2006) Phaenomena, pp. 451-455 (English edition: Mair GA) Loeb Classical Library 129. Harvard University Press, Cambridge, Massachusetts, London, $p$ 243

Crijns M (2002) The Lion Horoscope. In: Moormann EM, Versluy M-J (eds) The Nemrud Dag Project: first interim report, Babesch, Vol. 77, pp 97-99. https:// www.academia.edu/40253150/The_Lion_horoscope_proposal_for_a_new_dating and https://repository.ubn.ru.nl//bitstream/handle/2066/105757/M_184943.pdf

Crijns MLA (2014) Astro-religion in Commagene. In: Brijder HAG (ed) Nemrud Dağı, Recent Archaeological Research and Conservation Activities in the Tomb Sanctuary on Mount Nemrud. De Gruyter, Boston and Berlin, pp 563-599

Dörner FK (1987) Der Thron der Götter auf dem Nemrud Dag: Kommagene, das grosse archäologische Abenteuer in der östlichen Türkei. Gustav Lübbe Verlag, Bergisch Gladbach, p 240

Dörner FK, Goell ThB (1963) Arsameia am Nymphaios: Die Ausgrabungen im Hierothesion des Mithradates Kallinikos von 1953-1956. Istanbuler Forschungen, Vol. 23, Gebr. Mann, Berlin, p 68

Dörner FK, Young JH (1996) Sculpture and Inscription Catalog. In: Sanders DH (ed) Nemrud Dağı, The Hierothesion of Antiochus I of Commagene: results of the American excavations directed by Th.B. Goell, Eisenbrauns, Winona Lake, Indiana, pp 175-360
Diodorus, 1.81 .4 in Bowen A (2018) Hellenistic Astronomy. In Keyser P, Scarborough J (eds) The Oxford Handbook of Science and Medicine in the Classical World, Oxford University Press, Oxford, p 298. https://books.google.nl/books? id=TixhDwAAQBAJ\&pg=PA298\&lpg=PA298\&dq=Diodorus, +1.81 .4 . \&source=bl\&ots=ml_MlEM0pi\&sig $=$ ACfU3U1eJYhFnolxuOOTPlv2n UWjQQrQ\&hl $=$ nl\&sa $=$ X\&ved $=2$ ahUKEwil2YnV7aHpAhUD3qQKHa5oC3wQ6AEwAHoECAgQAQ\#v=onepage\&q=Diodorus\%2C\%201.81.4.\&f=false

Gautschy R (2011) Der Stern Sirius im Alten Ägypten. In: Zeitschrift für Ägyptische Sprache und Altertumskunde 138, Vol. 2, pp 116-131. https://edoc. unibas.ch/21752/

Hesiod (2004) Works and Days, pp 565-570 (English edition: Athanassakis, A.N., p 79). The Johns Hopkins University Press, Baltimore, London

de Jong T (2006) The Heliacal Rising of the Sun. In: Horning E, Krauss R, Warburton D (eds) Ancient Egyptian Chronology, Handbook of Oriental Studies 1, The Near and Middle East, Vol. 83. Brill, Leiden, pp 432-438. https://www.academia. edu/4161244/Hornung_Erik_Ancient_Egyptian_Chronology_Handbook_of_ Oriental_Studies_I_the_Near_and_Middle_East. See ref. 11, AMS. See ref. 11, AES

Koenen L (1977) Eine agonistische Inschrift aus Ägypten und frühptolemäische Königsfeste. In Beiträge zur klassischen Philologie, Vol. 56. Verlag Anton Hain KG, Meisenheim am Glan, p 73

Manning JG (2012) The Last Pharaohs: Egypt Under the Ptolemies, 305-30 BC. Princeton University Press, Princeton

Michell JA (1977) Little history of astro-archaeology. Thames \& Hudson, London, p 20 Parker RA (1950) The Calendars of Ancient Egypt. In: Allen TG (ed.) Studies in Ancient Oriental Civilization, Vol 26. The University of Chicago Press, Chicago

Robinson MJ (2009) Ardua et Astra: On the Calculation of the Dates of the Rising and Setting of Stars. In: Classical Philol 3, 104:354-375. https://discovery.ucl. ac.uk/id/eprint $/ 4840 /$

The Nemrud Dag Project: first interim report. https://repository.ubn.ru.nl// bitstream/handle/2066/105757/M_184943.pdf. See ref. 2, p 585

Varisco DM (1993) The Agricultural Marker Stars. In Yemeni Folklore Asian Folk Stud 52(1):19-142. https://www.jstor.org/stable/i250348

Walbank FW (2006) Polybius, Rome, and the Hellenistic World. Cambridge University Press, Cambridge, $\mathrm{p} 80$

Wallis Budge EA (1913) The Rosetta Stone. Harrison and Sons, London, pp 3-5. https://archive.org/details/rosettastone00budguoft/page/n4/mode/lup

\section{Acknowledgements}

The author likes to thank Jan Rademaker for his astronomical advice and Olga Boon, Marianne Pütz, and Herman Brijder for proofreading. The article is dedicated to Sir Norman Lockyer.

\section{Competing interests}

The author declares no competing interests.

\section{Additional information}

Supplementary information is available for this paper at https://doi.org/10.1057/s41599020-0496-2.

Correspondence and requests for materials should be addressed to M.C.

Reprints and permission information is available at http://www.nature.com/reprints

Publisher's note Springer Nature remains neutral with regard to jurisdictional claims in published maps and institutional affiliations.

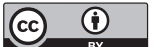

Open Access This article is licensed under a Creative Common Attribution 4.0 International License, which permits use, sharing, adaptation, distribution and reproduction in any medium or format, as long as you give appropriate credit to the original author(s) and the source, provide a link to the Creative Commons license, and indicate if changes were made. The images or other third party material in this article are included in the article's Creative Commons license, unless indicated otherwise in a credit line to the material. If material is not included in the article's Creative Commons license and your intended use is not permitted by statutory regulation or exceeds the permitted use, you will need to obtain permission directly from the copyright holder. To view a copy of this license, visit http://creativecommons.org/ licenses/by/4.0/

(c) The Author(s) 2020 